\title{
The Assessment of Air Pollution during 2013 and 2014 in Tokat Province
}

\author{
Ömer Işildak \\ Department of Chemistry, Faculty of Science and Education, Gaziosmanpaşa University, Tokat, Turkey
}

\begin{abstract}
This study aimed to determine the amount of total polluting matter emitted into the atmosphere from heating and industrial-based emissions and the total pollution bulk of Tokat city center. The annual cycles of some heavy metal in particulate matters have been investigated at this area in order to elucidate temporal variations as well as major sources processes responsible for their formation. Air particulate samples were collected from three different locations situated around Tokat. These samples were determined for heavy metals by using Flame or graphite-furnace Atomic absorption spectroscopy. Particulate matter concentrations up to $52.43 \mu \mathrm{g} / \mathrm{m}^{3}$ were observed in sampling area. The initial results of the chemical analysis showed that concentration values of heavy metals in air particles observed were higher than the World Health Organization (WHO) guideline limit values.
\end{abstract}

Key words: Air pollution, particle matter, $\mathrm{PM}_{10}$ and $\mathrm{PM}_{2,5}$.

\section{Background}

Air pollution is the introduction of particulates, biological molecules, or other harmful materials into Earth's atmosphere, causing diseases, death to humans, damage to other living organisms such as animals and food crops, or the natural or built environment. Air pollution may come from anthropogenic or natural sources [1-3].

Tokat economy is based on agriculture and agriculture-related industry widely. All kinds of products are grown in the fertile plains of Tokat. Livestock is also quite advanced. Tokat province is located in an area which promotes development and industrialization. As it is still an industrially developing city, it is necessary to be aware of the dimensions of the air pollution when one makes plans to solve this problem.

Air pollution is usually concentrated in densely populated metropolitan areas, especially in developing countries where environmental regulations are generally relatively lax or nonexistent [4-7].

The chemical composition of aerosols is known to

Corresponding author: Ömer Işildak, professor, research fields: analitical chemistry and environment pollution. be influenced mainly by the origin of aerosol particles. Such information is hence important for the proper apportionment of different source contributions from different sources $[2,3]$. It is generally understood that particles in the atmosphere are produced either from natural sources (such as wind-borne dust, sea spray, and volcanoes), anthropogenic activities (such as manufacturing products from raw material, combustion of fuel, mining and smelting activities, construction works, vehicular movements, etc.) and chemical reactions in the atmosphere.

This study aims to analyze the chemical concentration of selected pollutants in aerosol particles collected in Tokat city, Turkey. The region has not been previously investigated in detail. Tokat is located in Central Black Sea Region and has transition climates. Determination of the anion, cation and heavy metal concentrations in atmospheric particulates can provide useful information on pollution sources, probability of long-distance transportation of suspended particles and effects on human health [8-10]. Human health may be affected by aerosols in the environment. For instance, there is substantial evidence that a high $\mathrm{Pb}$ level in the environment could 
affect blood $\mathrm{Pb}$ level, intelligence, and behavior [6]. It has been noted that children could ingest dusts including heavy metals via their hands or mouths [7].

\section{Methods}

Air particulate samples were collected from three different locations situated around Tokat. Sampling stations had wide open surroundings. Aerosol samples were collected using a high volume air sampler developed in our laboratory. Sampling systems having flow rate of $12 \mathrm{~L} / \mathrm{min}$ can filter $17 \mathrm{~m}^{3}$ of air in a day. All samplings at each site were performed between $12.00 \mathrm{am}$ and $12.00 \mathrm{am}$ the next day. The filtering material sheets of $4.7 \mathrm{~cm}$ diameter were used with a plastic stamp to avoid metal contamination. The filters collected an average mass of $20 \mathrm{mg}$ of air particulate matter in a single experiment. Air particulate samples were collected during November 1, 2013 to October 31, 2014.

\section{Sample Preparation}

The samples for the analysis of heavy metals were extracted into acid solutions using a hot plate in the following sequence. Filter samples were placed in a Teflon container and treated initially by concentrated acid solutions ( $3 \mathrm{~mL} \mathrm{HNO}_{3}, 1 \mathrm{~mL} \mathrm{H}_{2} \mathrm{SO}_{4}, 1 \mathrm{~mL} \mathrm{H}_{2} \mathrm{O}_{2}$ ) (suprapur, Merck), evaporated to dryness, heated again at $60{ }^{\circ} \mathrm{C}$, treated with $1 \mathrm{~mL}$ concentrated $\mathrm{H}_{2} \mathrm{SO}_{4}$ (suprapur, Merck), $1 \mathrm{~mL} \mathrm{HNO}_{3}$ and $1 \mathrm{~mL} \mathrm{H}_{2} \mathrm{O}_{2}$ (suprapur, Merck), and then diluted with double deionized water up to a volume of $10 \mathrm{~mL}$. Blank filters were also treated in the same manner with sample filters to check the heavy metal impurities [11].

\section{Results and Discussion}

The concentrations of ionic and heavy metal species causing air pollution in Tokat were investigated for a period of 12 months. The mass variations of particulates calculated are shown in Fig. 1. For the detection of air pollution in the province of Tokat. Meteorological conditions have been identified, sulphur dioxide $\left(\mathrm{SO}_{2}\right)$ and suspended particulate matter (PM) measurements were taken which are presented in Table 1. The annual average and seasonal variation of all ion contents and heavy metals showed that the values obtained were much higher than the values recommended by the World Health Organization (WHO) Anthropogenic and crustal sources were expected to make significant contributions

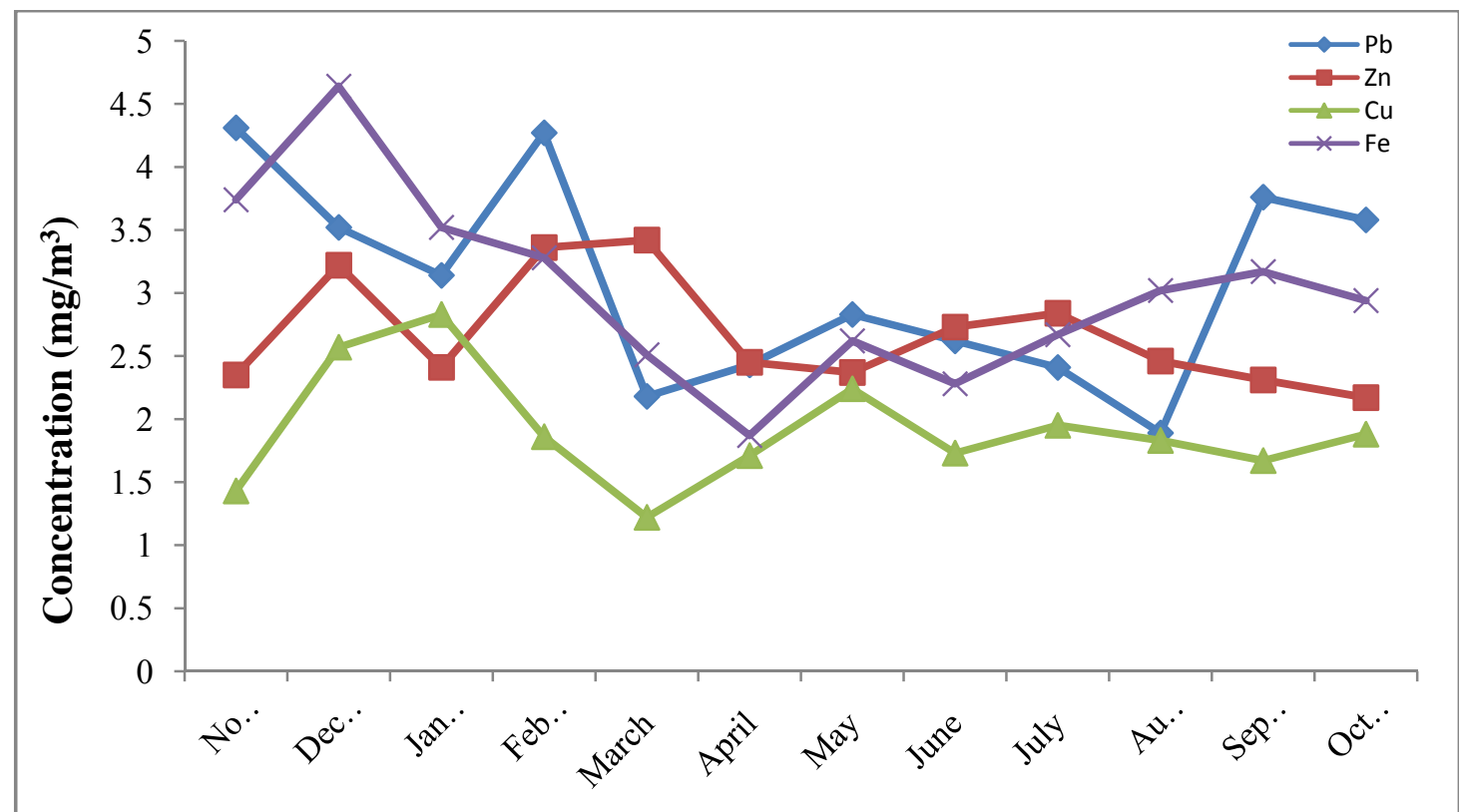

Fig. 1 Mass concentration variations of heavy metals from sampling area $\left(\mu \mathrm{g} / \mathrm{m}^{3}\right)$. 
Table 1 Climate and annual average $\mathrm{PM}_{10}$, and $\mathrm{SO}_{2}$ values of Tokat Province.

\begin{tabular}{lllllllll}
\hline & & $\mathrm{PM}_{10}\left(\mu \mathrm{g} / \mathrm{m}^{3}\right)$ & $\mathrm{SO}_{2}\left(\mu \mathrm{g} / \mathrm{m}^{3}\right)$ & Windspeed $(\mathrm{m} / \mathrm{s})$ & $\begin{array}{l}\text { Wind direction } \\
(\text { degree })\end{array}$ & Temp. $\left({ }^{\circ} \mathrm{C}\right)$ & $\begin{array}{l}\text { Relativehumi } \\
\text { dity }(\%)\end{array}$ & Airpressure $(\mathrm{mb})$ \\
\hline \multirow{2}{*}{2013} & Minimum & 17.24 & 6.33 & 10 & ENSE & -24 & 15 & 928 \\
& Maximum & 52.43 & 37.27 & 19 & ENE & 46 & 64 & 960 \\
\hline \multirow{2}{*}{2014} & Minimum & 6.57 & 3.17 & 8 & ENSE & -21 & 19 & 933 \\
& Maximum & 44.21 & 26.52 & 17 & ENE & 45 & 68 & 967 \\
\hline
\end{tabular}

Table 2 Heavy metals concentration levels in filter samples analyzed.

\begin{tabular}{lllll}
\hline & $\mathrm{Pb}$ & $\mathrm{Zn}$ & $\mathrm{Cu}$ & $\mathrm{Fe}$ \\
\hline November & $4.31 \pm 0.54$ & $2.35 \pm 0.55$ & $1.43 \pm 0.34$ & $3.74 \pm 0.65$ \\
December & $3.52 \pm 0.37$ & $3.22 \pm 0.94$ & $2.57 \pm 0.27$ & $4.64 \pm 0.83$ \\
January & $3.14 \pm 0.42$ & $2.41 \pm 0.61$ & $2.83 \pm 0.33$ & $3.52 \pm 0.68$ \\
February & $4.27 \pm 0.79$ & $3.36 \pm 0.82$ & $1.86 \pm 0.45$ & $3.28 \pm 0.71$ \\
March & $2.18 \pm 0.31$ & $3.42 \pm 0.88$ & $1.22 \pm 0.34$ & $2.51 \pm 0.66$ \\
April & $2.43 \pm 0.35$ & $2.45 \pm 0.47$ & $1.71 \pm 0.38$ & $1.87 \pm 0.53$ \\
May & $2.83 \pm 0.28$ & $2.37 \pm 0.63$ & $2.24 \pm 0.51$ & $2.62 \pm 0.49$ \\
June & $2.62 \pm 0.37$ & $2.73 \pm 0.53$ & $1.73 \pm 0.28$ & $2.28 \pm 0.62$ \\
July & $2.41 \pm 0.33$ & $2.84 \pm 0.49$ & $1.95 \pm 0.22$ & $2.67 \pm 0.37$ \\
August & $1.89 \pm 0.26$ & $2.46 \pm 0.54$ & $1.83 \pm 0.26$ & $3.02 \pm 0.72$ \\
September & $3.76 \pm 0.66$ & $2.31 \pm 0.37$ & $1.67 \pm 0.25$ & $3.17 \pm 0.84$ \\
October & $3.58 \pm 0.58$ & $2.17 \pm 0.42$ & $1.88 \pm 0.29$ & $2.94 \pm 0.57$ \\
\hline
\end{tabular}

to the air pollution in Tokat. $\mathrm{Pb}, \mathrm{Zn}$ and $\mathrm{Fe}$ concentrations in air particulate matter were found to be considerably high (Table 2 ). These species play a significant role in the atmospheric pollution. The possible source of atmospheric pollution is the large and middle sized industrial factories in this region. Higher winter concentrations of heavy metals can be attributed to intense coal combustion in addition to emissions from industrial sectors in the region.

The concentrations of $\mathrm{Pb}$ and $\mathrm{Zn}$ were higher in air particles, which were mainly due to the traffic density and direct emission of exhaust gases into the atmosphere. Use of insecticides, pesticides and fertilizers in agricultural activities has grown quite a lot. They emit harmful chemicals into the air and can also cause water pollution.

WHO considering that limit values for $\mathrm{PM}_{10}(10$ $\mu \mathrm{g} / \mathrm{m}^{3}$ annual average $)$ and $\mathrm{SO}_{2}\left(20 \mu \mathrm{g} / \mathrm{m}^{3}\right.$ annual average) advised, Tokat province seems to be exceeded in the atmosphere [12]. As a solid fuel for heating in Tokat, imported coal, wood and domestic coal are used.

Air pollution from heating, not only limited to the residential areas and industrial zones within the city limits but also because of all the spread of pollutants into the atmosphere is causing a local problem. Therefore, taking into consideration the measurement values emission inventory of the province, meteorological data and air pollution require the determination of a regional strategy in the studies for the prevention of air pollution sourced from warming.

WHO suggested a $0.50 \mu \mathrm{g} / \mathrm{m}^{3}$ limit value for $\mathrm{Pb}$ in air particles. In this study, $\mathrm{Pb}$ concentration in air sampling was found to be higher than these suggested values with lowest $1.89 \mu \mathrm{g} / \mathrm{m}^{3}$ values. The highest $\mathrm{Pb}$ content was obtained as $4.31 \mu \mathrm{g} / \mathrm{m}^{3}$.

The highest $\mathrm{Zn}$ concentration was found to be in sampling area as $3.42 \pm 0.88 \mathrm{mg} / \mathrm{m}^{3}$ while the lowest $\mathrm{Zn}$ concentration was obtained in air particles $(2.17 \pm$ $\left.0.42 \mu \mathrm{g} / \mathrm{m}^{3}\right)$.

The limit values for $\mathrm{Cu}$ in air particulate as recommended by DEC are $0.10 \mu \mathrm{g} / \mathrm{m}^{3}$ per day as the annual average and $5.00 \mu \mathrm{g} / \mathrm{m}^{3}$ as the daily average. $\mathrm{Cu}$ concentrations are also found to be considerably high in air particulate samples. The highest concentration of $\mathrm{Cu}$ was found as $2.83 \pm 0.33 \mu \mathrm{g} / \mathrm{m}^{3}$. 
The highest $\mathrm{Fe}$ concentration was determined as $4.64 \pm 0.83 \mu \mathrm{g} / \mathrm{m}^{3}$ in sampling area. The lowest $\mathrm{Fe}$ content was found to be $1.87 \pm 0.53 \mu \mathrm{g} / \mathrm{m}^{3}$ in air particles.

\section{Conclusions}

In this present study, the air quality of Tokat region in Turkey has been investigated. The results found indicate considerably high concentrations of heavy metals and particulate matters particularly in air samples. The mass and concentration levels of particulate matter in sampling area were well above the standards of particulate matter pollution. High level PM concentrations were measured in each sampling site. Heavy metal concentrations in the different particulate matters emitted atmosphere were detected as higher than the limit values suggested by global health organizations.

\section{References}

[1] Isildak, O. 2011. "Determination of Ion Concentrations and Heavy Metals in the Air Particulates of an Industrial Area." Karaelmas Science and Engineering Journal 1 (2): 49-54.

[2] Mishra, V., Kim, K. H., Hong, S., and Lee, K. 2004. "Aerosol Composition and İts Sources at the King Sejong Station, Antarticpeninsula." Atmospheric Environment 38: 4069.

[3] Henning, S., Weingartner, E., Schwikowski, M., Gaggeler, H. W., Gehring, R., Hinz, K. P., Trimborn, A., Spengler, B., and Baltensperger, U. 2003. "Seasonal
Variation of Water-solubleions of the Aerosol at the High-alpine Site Jungfraujoch (3,589 m asl)." Journal of Geophysical Research 18 (D1): 8-10.

[4] Cabada, J. C., Rees, S., Takahama, S., Khlystov, A., Pandis, S. N., Davidson, C. I., and Robinson, A. L. 2004. "Mass Size Distributions and Size Resolved Chemical Composition of Fine Particulate Matter at the Pittsburgh Supersite." Atmospheric Environment 38: 3127-41.

[5] Hamamci, C., Gumgum, B., Akba, O., and Erdogan, S. 1997. "Lead in Urban Street Dust in Diyarbakir, Turkey." Fresenius Environ. Bull. 6: 430-7.

[6] McMichael, A. J., Baghurst, P. A., Robertson, E. F., Vimpani, G. V., and Wigg, N. R. 1985. "The Port Piriestudy: Blood Lead Concentrations in Early Childhood." Med. J. Aust. 143: 499-503.

[7] Watt, J., Thornton, I., and Cotter-Howells, J. 1993. "Physical Evidence Suggesting the Transfer of Soil $\mathrm{Pb}$ into Young Children via Hand-to-Mouth Activity." Appl. Geochem. 2: 269-72.

[8] Adriano, D. C. 1986. Trace Elements in the Terrestrial Environment. New York: Springer-Verlag.

[9] Tu, J., Wang, H., Zhang, Z., Jin, X., and Li, W. 2005. "Trends in Chemical Composition of Precipitation in Nanjing, China, during 1992-2003." Atmospheric Environment 73: 283-98.

[10] Fujita, S., Takahashi, A., Hayami, H., and Sakurai, T. 2001. "Long-Term Trends in the Chemical Composition of Precipitation over Western Japan." Water Air Soil Pollutant 130: 415-20.

[11] Rizzio, E., Giaveri, G., and Gallorini, M. 2000. "Some Analytical Problems Encountered for Trace Elements Determination in the Airborne Particulate Matter of Urban and Rural Areas." Sci. Total Environ. 256: 11-22.

[12] WHO. 1987. Air Quality Guidelines, for Europe, Regional Office for Europe, Copenhagen. 